\title{
Features of import substitution in the agro- industrial complex of the Rostov region
}

\author{
Elvira Cherkesova ${ }^{1}$, Daria Mironova ${ }^{1,{ }^{*}}$, Nataliya Demidova ${ }^{1}$ \\ ${ }^{1}$ Institute of service and entrepreneurship (branch of Don State Technical University), 147, \\ Shevchenko str., 346500, Shakhty, Russia
}

\begin{abstract}
Economic and food security are becoming a priority for the development of the state in conditions of high political instability and disruption of foreign economic relations. The products of the agroindustrial complex play an important role in ensuring the life of the country's citizens. This study provides a horizontal analysis of the dynamics of production and consumption of the main types of meat and dairy products in the Rostov region, and a vertical analysis of the structure of meat products in the region. The study also reveals the reasons for the negative dynamics of the main indicators of the region's food supply for the meat and dairy industries. This work reflects the features of the state policy of import substitution in the agro-industrial complex. The article explores the issues of effective functioning of the subjects of the agroindustrial complex in the conditions of sanctions pressure of Western countries. In conclusion, priority directions for improving the mechanisms of state regulation of the agricultural sector are given. The article gives some recommendations on improving the mechanisms of state support and stimulating of import substitution in the agro-industrial complex.
\end{abstract}

\section{Introduction}

In the 2010s, the share of imported food products in the commodity resources of retail trade in Russia was about a third [1]. High dependence on imports posed a threat to the country's food and economic security. The Western sanctions imposed on Russia in 2014 and the reciprocal embargo on agricultural imports strengthened the importance of a substantial increase in production and the provision of import substitution in the agricultural sector [2].

The agro-industrial complex of the region (AIC) is the largest association of interconnected sectors of the economy involved in the production, processing, storage and delivery of agricultural products to consumers. The main task of the agro-industrial complex is the most complete and diverse satisfaction of consumer demand in food, raw materials and consumer goods [3].

By self-sufficiency is meant the satisfaction of the needs of the region at the expense of local production, using only internal capabilities and reserves for the development and expansion of local production. This is the most complete satisfaction of the existing social

\footnotetext{
${ }^{*}$ Corresponding author: mironova06-86@inbox.ru
} 
and economic needs of the territory in resources due to its own production, significant expansion of horizontal economic ties, deepening of cooperation and integration of production, independent participation in the international and regional division of labor on the basis of an equivalent exchange of goods, works and services [4].

Currently, as noted by many researchers (V. P. Samarina [5], E. G. Animitsa [6], etc.), the problem of import substitution is becoming more urgent, both at the regional and Federal level, in the context of the economic security of the state.

The purpose of this study is to analyze the self-sufficiency of the Rostov region with milk, dairy and meat products and to develop proposals for improving the mechanisms of state regulation of the agricultural sector in the context of the implementation of the import substitution policy. Based on this goal, the following tasks are formed:

- to conduct a horizontal analysis of the dynamics of production of the main types of meat and dairy products of the Rostov region for 2014-2018;

- to perform a horizontal analysis of the dynamics of consumption of meat and dairy products for 2014-2018;

- to perform a vertical analysis of the structure of meat products in the region for 2014 and 2018;

- to analyze the self-sufficiency of the Rostov region with dairy and meat products;

- to offer recommendations on improving the mechanisms of state support and stimulating of import substitution in the agro-industrial complex of the Russian Federation.

\section{Materials and Methods}

The study analyzes the data of the Federal and territorial services of state statistics. Methods of statistical, economic and logical analysis, comparison and grouping methods, principles of consistency and development are used in the work.

The Rostov region is one of the largest agro-industrial centers in Russia with a high level of development of agriculture and food processing industry.

Along with food production, meat industry enterprises produce dry animal feed, valuable medical products (insulin, heparin, linocaine), as well as gues, gelatin, and feather products.

The meat industry of the Rostov region is represented by such enterprises as: Donmyasoproduct LLC, Tavr LLC, Grantmit LLC, Tsaritsyno-Don LLC, Indolina Trading House, etc.

The dairy industry unites enterprises that produce various dairy products from milk, as well as enterprises that produce animal oil, whole milk products, canned milk, milk powder, cheese, feta cheese, ice cream, casein and other dairy products.

The dairy industry of the Rostov Region is represented by the following enterprises: Azov Dairy Plant LLC, Volgodonsky Dairy Plant CJSC, Rostov Processed Cheese Plant LLC, Polar Bear LLC, Taganrog-Milk OJSC, Radonezh CJSC, OJSC dairy factory "Orlovskiy" and others.

Table 1 presents the recommended consumption volumes of meat and dairy products on average per person in the Rostov region.

Table 1. Recommended consumption volumes.

\begin{tabular}{|l|c|}
\hline \multicolumn{1}{|c|}{ Product Groups } & Recommended Volumes \\
\hline Meat and meat products & $70-75 \mathrm{~kg} /$ year/person \\
\hline Milk and dairy products in terms of milk & $320-340 \mathrm{~kg} /$ year/person \\
\hline
\end{tabular}


Rostov region is considered a strong region in agriculture, but the production of milk and meat is not as good as the production of grain. We will conduct a horizontal analysis of the dynamics of production of the main types of meat products in the Rostov region (table 2).

A horizontal analysis of the dynamics of production of the main types of meat products in the Rostov region indicates the presence of negative trends in 2018 compared to previous years, expressed in a decrease in the volume of production of this product.

Table 2. Horizontal analysis of the dynamics of production of the main types of meat products, thousand tons.

\begin{tabular}{|c|c|c|c|c|c|c|c|c|c|c|c|c|c|}
\hline \multirow{3}{*}{$\begin{array}{c}\text { Name } \\
\text { of } \\
\text { produ } \\
\text { ct } \\
\text { types }\end{array}$} & \multirow[b]{3}{*}{$\begin{array}{c}201 \\
4\end{array}$} & \multirow[b]{3}{*}{$\begin{array}{c}201 \\
5\end{array}$} & \multirow[b]{3}{*}{$\begin{array}{c}201 \\
6\end{array}$} & \multirow[b]{3}{*}{$\begin{array}{l}\mathbf{2 0} \\
17\end{array}$} & \multirow[b]{3}{*}{$\begin{array}{l}20 \\
18\end{array}$} & \multicolumn{8}{|c|}{ Changes } \\
\hline & & & & & & \multicolumn{2}{|c|}{ 2016-2015 } & \multicolumn{2}{|c|}{$2017-2016$} & \multicolumn{2}{|c|}{ 2018-2017 } & \multicolumn{2}{|c|}{ 2018-2014 } \\
\hline & & & & & & $+/-$ & $\begin{array}{c}\text { Gro } \\
\text { wth } \\
\text { rate. } \\
\%\end{array}$ & $+/-$ & $\begin{array}{c}\text { Gro } \\
\text { wth } \\
\text { rate. } \\
\%\end{array}$ & $+/-$ & $\begin{array}{c}\text { Gro } \\
\text { wth } \\
\text { rate. } \\
\%\end{array}$ & $+/-$ & $\begin{array}{c}\text { Gro } \\
\text { wth } \\
\text { rate. } \\
\%\end{array}$ \\
\hline 1 & 2 & 3 & 4 & 5 & 6 & 7 & 8 & 9 & 10 & 11 & 12 & 13 & 14 \\
\hline 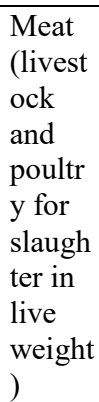 & $\begin{array}{r}29 . \\
6\end{array}$ & $\begin{array}{r}25 . \\
9\end{array}$ & $\begin{array}{r}22 . \\
8\end{array}$ & $\begin{array}{r}37 . \\
8\end{array}$ & $\begin{array}{r}34 . \\
8\end{array}$ & $\begin{array}{r}3 . \\
1\end{array}$ & 88.0 & $\begin{array}{r}15 . \\
0\end{array}$ & 165.8 & $\begin{array}{r}3 . \\
0\end{array}$ & 92.1 & 5.2 & 117.6 \\
\hline $\begin{array}{l}\text { Beef } \\
\text { steame } \\
\text { d. } \\
\text { cooled } \\
\text { chilled }\end{array}$ & 5.6 & 4.6 & 6.0 & 0.6 & 1.1 & $\begin{array}{l}1 . \\
4\end{array}$ & 130.4 & -5.4 & 10.0 & $\begin{array}{r}0 . \\
5\end{array}$ & 183.3 & -4.5 & 19.6 \\
\hline $\begin{array}{l}\text { Pork } \\
\text { steam. } \\
\text { cooled } \\
\text { chilled }\end{array}$ & $\begin{array}{r}19 . \\
1\end{array}$ & $\begin{array}{r}16 . \\
2\end{array}$ & $\begin{array}{r}12 . \\
1\end{array}$ & 0.9 & 1.1 & $\begin{array}{r}- \\
4 . \\
1\end{array}$ & 74.7 & $\begin{array}{r}- \\
21\end{array}$ & 7.6 & $\begin{array}{r}0 . \\
1\end{array}$ & 114.1 & $\begin{array}{r}- \\
18 .\end{array}$ & 5.5 \\
\hline $\begin{array}{l}\text { Meat } \\
\text { and } \\
\text { edible } \\
\text { offal } \\
\text { of } \\
\text { poultr } \\
\text { y }\end{array}$ & $\begin{array}{r}75 . \\
6\end{array}$ & $\begin{array}{r}84 . \\
8\end{array}$ & $\begin{array}{r}98 . \\
5\end{array}$ & $\begin{array}{r}13 . \\
9\end{array}$ & 0.6 & $\begin{array}{r}13 \\
.7\end{array}$ & 116.2 & $\begin{array}{r}- \\
84 .\end{array}$ & 14.1 & $\begin{array}{r}- \\
13 \\
.3\end{array}$ & 4.2 & $\begin{array}{r}- \\
75 . \\
0\end{array}$ & 0.8 \\
\hline $\begin{array}{l}\text { Sausa } \\
\text { ge } \\
\text { produc } \\
\text { ts }\end{array}$ & $\begin{array}{r}51 . \\
3\end{array}$ & $\begin{array}{r}52 . \\
6\end{array}$ & $\begin{array}{r}50 . \\
7\end{array}$ & $\begin{array}{r}34 . \\
1\end{array}$ & 3.5 & $\begin{array}{c}- \\
1 . \\
9\end{array}$ & 96.4 & $\begin{array}{r}16 . \\
6\end{array}$ & 67.3 & $\begin{array}{r}30 \\
.6\end{array}$ & 10.4 & $\begin{array}{r}- \\
47\end{array}$ & 6.9 \\
\hline Total: & $\begin{array}{r}181 \\
.2\end{array}$ & $\begin{array}{r}184 \\
.1\end{array}$ & $\begin{array}{r}190 \\
.1\end{array}$ & $\begin{array}{r}87 . \\
3\end{array}$ & $\begin{array}{r}41 . \\
1\end{array}$ & $\begin{array}{r}6 . \\
0\end{array}$ & 103.3 & $\begin{array}{r}- \\
102 \\
.8 \\
\end{array}$ & 45.9 & $\begin{array}{r}- \\
46 \\
.3 \\
\end{array}$ & 47.0 & $\begin{array}{r}- \\
140 \\
.1 \\
\end{array}$ & 22.7 \\
\hline
\end{tabular}

The analysis showed that the total volume of meat production in 2018 amounted to 41.1 thousand tons, which is 140.1 thousand tons or $77.3 \%$ less than in 2014 . In 2015-2016, 
it was possible to observe a positive trend, indicating an increase in production volumes, so the total production of meat products in 2015 amounted to 184.1 thousand tons, and in 2016 190.1 thousand tons. In 2017, there was the first wave of rapid decline in production, which reached 87.3 thousand tons, which is 102.8 thousand tons or $54.1 \%$ less than in 2016 . In 2018 , only 41.1 thousand tons of meat products were produced $(22.7 \%$ of the 2014 volume).

Let us analyze the structure of production of the main types of meat products for 2014 and 2018 (table 3).

Table 3. Analysis of the production structure of the main types of meat products for 2014 and 2018 , thousand tons.

\begin{tabular}{|c|c|c|c|c|c|c|}
\hline \multirow{2}{*}{$\begin{array}{c}\text { Name of product } \\
\text { types }\end{array}$} & \multirow{2}{*}{2014} & \multirow{2}{*}{$\begin{array}{c}\text { Specific } \\
\text { weight. } \\
\text { in } \%\end{array}$} & \multirow{2}{*}{2018} & \multirow{2}{*}{$\begin{array}{c}\text { Specific } \\
\text { weight. } \\
\text { in } \%\end{array}$} & \multicolumn{2}{|c|}{$\begin{array}{l}\text { Deviations of data for the } \\
\text { reporting year in comparison } \\
\text { with the previous one }\end{array}$} \\
\hline & & & & & $\begin{array}{c}\text { Absolute } \\
\text { (4-2) }\end{array}$ & $\begin{array}{c}\text { Relative (5-3). p. } \\
\text { p. }\end{array}$ \\
\hline 1 & 2 & 3 & 4 & 5 & 6 & 7 \\
\hline $\begin{array}{l}\text { Meat (livestock } \\
\text { and poultry for } \\
\text { slaughter in live } \\
\text { weight) }\end{array}$ & 29.6 & 16.3 & 34.8 & 84.7 & 5.2 & 68.4 \\
\hline $\begin{array}{l}\text { Beef steamed. } \\
\text { cooled. chilled }\end{array}$ & 5.6 & 3.1 & 1.1 & 2.7 & -4.5 & -0.4 \\
\hline $\begin{array}{l}\text { Pork steam. } \\
\text { cooled. chilled }\end{array}$ & 19.1 & 10.5 & 1.1 & 2.7 & -18.0 & -7.8 \\
\hline $\begin{array}{l}\text { Meat and edible } \\
\text { offal of poultry }\end{array}$ & 75.6 & 41.7 & 0.6 & 1.5 & -75.0 & -40.3 \\
\hline Sausage products & 51.3 & 28.3 & 3.5 & 8.5 & -47.8 & -19.8 \\
\hline Total: & 181.2 & 100.0 & 41.1 & 100.0 & -140.1 & - \\
\hline
\end{tabular}

Based on the analysis, we can conclude that there is a significant change in the structure of meat production in the Rostov region. In 2018, the share of meat production (livestock and poultry for slaughter in live weight) increased, which amounted to $84.7 \%$ or 34.8 thousand tons, which is 68.4 percentage points more than in 2014. Other types of meat products had changes in the structure as well, for example, the proportion of steamed, cooled and chilled beef decreased by 0.4 percentage points and amounted to $2.7 \%$ of the total meat production. In 2018, the share in production of steamed, cooled, and chilled pork also decreased- $2.6 \%$, which is 7.8 percentage points less than in 2014; sausage products $8.5 \%$, which is 19.8 percentage points less than in 2014 . The share of meat and poultry offal production was also reduced, if in 2014 it was $41.7 \%$ and 75.6 thousand tons were produced, then in 2018 it amounted to $1.5 \%$ and 0.6 thousand tons were produced, this is 40.2 percentage points or 75.0 thousand tons less than in 2014. Poultry meat is an important component of a healthy diet. In addition to the fact that this meat is rich in useful elements, it also has a price range that is affordable for a wide consumer. This explains the reason why in 2014 the share of poultry production accounted for the largest share of meat production in general, however, as mentioned earlier, in 2018 the production of this product sharply decreased. This trend is observed due to the closure of two large Rostov companies specializing in the production and cultivation of poultry-LLC "Eurodon", LLC "White bird".

Next, in table 4 we will conduct a horizontal analysis of the dynamics of production.

Table 4. Horizontal analysis of the dynamics of production of the main types of dairy products, thousand tons. 


\begin{tabular}{|c|c|c|c|c|c|c|c|c|c|c|c|c|c|}
\hline \multirow{3}{*}{$\begin{array}{c}\text { Name } \\
\text { of } \\
\text { produc } \\
\text { t types }\end{array}$} & \multirow{3}{*}{$\begin{array}{c}201 \\
4\end{array}$} & \multirow{3}{*}{$\begin{array}{c}201 \\
5\end{array}$} & \multirow{3}{*}{$\begin{array}{c}201 \\
6\end{array}$} & \multirow{3}{*}{$\begin{array}{c}201 \\
7\end{array}$} & \multirow{3}{*}{$\begin{array}{c}201 \\
8\end{array}$} & \multicolumn{8}{|c|}{ Changes } \\
\hline & & & & & & \multicolumn{2}{|c|}{ 2016-2015 } & \multicolumn{2}{|c|}{$\begin{array}{c}2017- \\
2016\end{array}$} & \multicolumn{2}{|c|}{ 2018-2017 } & \multicolumn{2}{|c|}{$\begin{array}{l}2018- \\
2014\end{array}$} \\
\hline & & & & & & $+/-$ & $\%$ & $+/-$ & $\%$ & $+/-$ & $\%$ & $+/-$ & $\%$ \\
\hline 1 & 2 & 3 & 4 & 5 & 6 & 7 & 8 & 9 & 10 & 11 & 12 & 13 & 14 \\
\hline $\begin{array}{l}\text { Milk } \\
\text { (whole } \\
\text { milk } \\
\text { product } \\
\text { s) }\end{array}$ & $\begin{array}{c}78 . \\
5\end{array}$ & $\begin{array}{c}112 . \\
4\end{array}$ & 99.8 & $\begin{array}{c}47 . \\
0\end{array}$ & $\begin{array}{c}69 . \\
7\end{array}$ & $\begin{array}{c}- \\
12 . \\
6\end{array}$ & 88.8 & $\begin{array}{c}- \\
52 . \\
8\end{array}$ & $\begin{array}{c}47 . \\
1\end{array}$ & $\begin{array}{c}22 . \\
7\end{array}$ & $\begin{array}{c}148 . \\
2\end{array}$ & $\overline{8.8}$ & $\begin{array}{c}88 . \\
8\end{array}$ \\
\hline Butter & 2.9 & 2.7 & 2.0 & 0.1 & 0.3 & $\begin{array}{c}- \\
0.7\end{array}$ & 74.1 & $\begin{array}{c}- \\
1.9\end{array}$ & 6.5 & 0.2 & $\begin{array}{c}215 . \\
4\end{array}$ & $\begin{array}{c}- \\
2.6\end{array}$ & $\begin{array}{c}10 . \\
3\end{array}$ \\
\hline $\begin{array}{l}\text { Cheese. } \\
\text { thousan } \\
\text { d tons } \\
\text { Cheese } \\
\text { product } \\
\text { s }\end{array}$ & 9.2 & 10.6 & 11.6 & 0.2 & 0.6 & 1 & $\begin{array}{c}109 \\
4\end{array}$ & $\begin{array}{c}11 . \\
4\end{array}$ & 1.6 & 0.4 & $\begin{array}{c}326 . \\
3\end{array}$ & ${ }^{-}$ & 6.7 \\
\hline Total: & $\begin{array}{c}90 . \\
6\end{array}$ & $\begin{array}{c}125 . \\
7\end{array}$ & $\begin{array}{c}113 . \\
4\end{array}$ & $\begin{array}{c}47 . \\
3\end{array}$ & $\begin{array}{c}70 . \\
6\end{array}$ & $\begin{array}{c}- \\
12 . \\
3\end{array}$ & 90.2 & $\begin{array}{c}- \\
66 . \\
1\end{array}$ & $\begin{array}{c}41 . \\
8\end{array}$ & $\begin{array}{c}23 . \\
3\end{array}$ & $\begin{array}{c}149 . \\
1\end{array}$ & $\begin{array}{c}- \\
20 . \\
0\end{array}$ & $\begin{array}{r}77 \\
9\end{array}$ \\
\hline
\end{tabular}

Horizontal analysis of the dynamics of production of the main types of dairy products in the Rostov region shows that the situation in milk and dairy products market is slightly better than in the market of meat and meat products. There are also negative trends that lead to a reduction in production for all types of dairy products presented in table 4 . So, the volume of milk production (whole milk products) in 2018 amounted to 69.7 thousand tons, which is $11.2 \%$ less than in 2014 . We can conclude that the maximum volume of production of these products falls on 2015-2016, which amounted to 112.4 thousand tons in 2015 , which is $43.2 \%$ more than in 2014 , and in 2016 - 99.8 thousand tons, which is $11.2 \%$ less than in 2015 , but $27.1 \%$ more than in 2014 . Then the volume of production begins to decline and in 2017 is already 47.0 thousand tons, which is $52.9 \%$ less than in 2016 . Compared to 2017, the situation in 2018 begins to stabilize, the production volume of these products is growing, which amounts to 69.7 thousand tons, which is $48.3 \%$ more than in 2017. After analyzing the production of butter, we can conclude that during these five years, the volume of production of these products gradually decreased. So, in 2018 it amounted to 0.3 thousand tons, which is $89.7 \%$ less than in 2014 . The following trend is observed in the production of cheeses and cheese products: during 2014-2016 there was a positive trend for the growth in the volume of production of these products, in 2015 it amounted to 10.6 thousand tons, which is $15.2 \%$ more than in 2014 , in $2016-11.6$ thousand tons, which is $9,4 \%$ higher than in 2015. However, in 2017, the production volume decreased by 11.4 thousand tons and amounted to 0.2 thousand tons, which is $98.3 \%$ less than in 2016. The situation has not changed much in 2018, although the volume of production has started to increase, but still slightly and amounted to 0.6 thousand tons, which is 0.4 thousand tons more than in 2017. Thus, from 2014 to 2018 , there was a decrease in the total production of dairy products by 20 thousand tons or $22.1 \%$, especially high rates of reduction are observed for the "Cheese" and "Butter" groups: 15 times and 9.7 times, respectively.

The decline in dairy production is due to the fact that, firstly, there is not enough raw materials for production, since the share of marketed milk is a little more than $30 \%$, and secondly, the produced products have nowhere to be sold, since a large volume of the market is occupied by products of Belarusian and Kuban production. Another reason for the reduction in production is the drop in the number of livestock. This is because in the 
climate of the Rostov region it is more profitable to sell grain than to produce dairy products.

Despite the fact that the level of production is falling, the consumption of meat and dairy products remains at a high level, this is indicated by the data presented in table 5 .

Table 5. Consumption of meat and dairy products of the population of the Rostov region, $\mathrm{kg}$.

\begin{tabular}{|c|c|c|c|c|c|}
\hline Name & 2014 & 2015 & 2016 & 2017 & 2018 \\
\hline 1 & 2 & 3 & 4 & 5 & 6 \\
\hline The population of the Rostov region & $\begin{array}{c}4245 \\
532 \\
\end{array}$ & $\begin{array}{c}4242 \\
080 \\
\end{array}$ & $\begin{array}{c}4236 \\
000 \\
\end{array}$ & $\begin{array}{c}4231 \\
355 \\
\end{array}$ & $\begin{array}{c}4220 \\
452 \\
\end{array}$ \\
\hline $\begin{array}{l}\text { Consumption of meat and meat } \\
\text { products per capita }\end{array}$ & 63 & 61 & 62 & 62 & 63 \\
\hline $\begin{array}{l}\text { Consumption of meat and meat } \\
\text { products of the population of the } \\
\text { Rostov region }\end{array}$ & $\begin{array}{c}267468 \\
516\end{array}$ & $\begin{array}{c}258766 \\
880\end{array}$ & $\begin{array}{c}262632 \\
000\end{array}$ & $\begin{array}{c}262344 \\
010\end{array}$ & $\begin{array}{c}265888 \\
476\end{array}$ \\
\hline $\begin{array}{l}\text { Consumption of milk and dairy } \\
\text { products per capita }\end{array}$ & 273 & 261 & 257 & 254 & 256 \\
\hline $\begin{array}{l}\text { Consumption of milk and dairy } \\
\text { products of the population of the } \\
\text { Rostov region }\end{array}$ & $\begin{array}{c}1159 \\
030236\end{array}$ & $\begin{array}{c}1107 \\
182880\end{array}$ & $\begin{array}{c}1088 \\
652000\end{array}$ & $\begin{array}{c}1074 \\
764170\end{array}$ & $\begin{array}{c}1080 \\
435712\end{array}$ \\
\hline
\end{tabular}

Next, in table 6, let us conduct a horizontal analysis of the dynamics of product consumption.

Table 6. Horizontal analysis of the dynamics of consumption of meat and dairy products, thousand tons.

\begin{tabular}{|c|c|c|c|c|c|c|c|c|c|c|c|c|c|}
\hline \multirow{3}{*}{ Name } & \multirow{3}{*}{2014} & \multirow{3}{*}{2015} & \multirow{3}{*}{2016} & \multirow{3}{*}{2017} & \multirow{3}{*}{2018} & \multicolumn{8}{|c|}{ Changes } \\
\hline & & & & & & \multicolumn{2}{|c|}{$\begin{array}{l}2016- \\
2015 \\
\end{array}$} & \multicolumn{2}{|c|}{$\begin{array}{c}2017- \\
2016 \\
\end{array}$} & \multicolumn{2}{|c|}{$\begin{array}{c}\text { 2018- } \\
2017 \\
\end{array}$} & \multicolumn{2}{|c|}{$\begin{array}{c}\text { 2018- } \\
2014 \\
\end{array}$} \\
\hline & & & & & & $+/-$ & $\%$ & $+/-$ & $\%$ & $\begin{array}{l}+1 \\
-\end{array}$ & $\%$ & $+/-$ & $\%$ \\
\hline 1 & 2 & 3 & 4 & 5 & 6 & 7 & 8 & 9 & 10 & $\begin{array}{l}1 \\
1\end{array}$ & 12 & 13 & 14 \\
\hline $\begin{array}{l}\text { Consump } \\
\text { tion of } \\
\text { meat and } \\
\text { meat } \\
\text { products } \\
\text { of the } \\
\text { populatio } \\
\text { n of the } \\
\text { Rostov } \\
\text { region }\end{array}$ & $\begin{array}{c}267 . \\
5\end{array}$ & $\begin{array}{c}258 . \\
8\end{array}$ & $\begin{array}{c}262 . \\
6\end{array}$ & $\begin{array}{c}262 . \\
3\end{array}$ & $\begin{array}{c}265 . \\
9\end{array}$ & 3.8 & $\begin{array}{c}101 \\
.5\end{array}$ & $\begin{array}{c}- \\
0.3\end{array}$ & $\begin{array}{c}99 . \\
9\end{array}$ & $\begin{array}{l}3 . \\
6\end{array}$ & $\begin{array}{c}101 \\
.4\end{array}$ & $\begin{array}{c}- \\
1.6\end{array}$ & $\begin{array}{c}99 . \\
4\end{array}$ \\
\hline $\begin{array}{l}\text { Consump } \\
\text { tion of } \\
\text { milk and } \\
\text { dairy } \\
\text { products } \\
\text { of the } \\
\text { populatio } \\
n \text { of the }\end{array}$ & $\begin{array}{c}1159 \\
.0\end{array}$ & $\begin{array}{c}1107 \\
.2\end{array}$ & $\begin{array}{c}1088 \\
.7\end{array}$ & $\begin{array}{c}1074 \\
.8\end{array}$ & $\begin{array}{c}1080 \\
.4\end{array}$ & $\begin{array}{c}18 . \\
5\end{array}$ & $\begin{array}{c}98 . \\
3\end{array}$ & $\begin{array}{c}- \\
13 . \\
9\end{array}$ & $\begin{array}{c}98 . \\
7\end{array}$ & $\begin{array}{l}5 . \\
6\end{array}$ & $\begin{array}{c}100 \\
.5\end{array}$ & $\begin{array}{c}- \\
78 . \\
6\end{array}$ & $\begin{array}{c}93 . \\
2\end{array}$ \\
\hline
\end{tabular}


Rostov

region

Based on the analysis, we can conclude that the consumption of meat and dairy products in 2014-2018 was at a consistently high level. Thus, the volume of consumption of meat and meat products in 2018 amounted to 265.9 thousand tons, which is $0.6 \%$ less than in 2014. The minimum volume of consumption of these products falls on $2015-258.8$ thousand tons, which is $3.3 \%$ less than in the previous year. In 2016, the consumption indicator amounted to 262.6 thousand tons, which is $1.5 \%$ more than in 2015 . Then, in 2017 , the volume amounted to 262.3 thousand tons, which is $0.1 \%$ less than in 2016 , but $1.4 \%$ more than in 2015. In 2018, there was an increase in the volume of consumption 265.9 thousand tons, which is $1.4 \%$ more than in 2017 . After analyzing the consumption of milk and dairy products, we can conclude that the volume of milk consumption is greater than the volume of meat consumption. In 2018, the volume of consumption of milk and dairy products decreased to 1080.4 thousand tons, which is $6.8 \%$ less than in 2014 . In 2015 2017 , there was also a decrease in volumes, in 2015 - 1107.2 thousand tons, which is $4.5 \%$ less than in 2014, in 2016 - 1088.7 thousand tons, which is $1.7 \%$ less than in 2015 and $6.1 \%$ less than 2014. The minimum volume of consumption was in 2017 and it was equal to 1074.8 thousand tons, which is 13.9 thousand tons or $1.3 \%$ less than in 2016 . In 2018 , the volume of consumption increased and reached 1080.4 thousand tons, more than in 2017 by 5.6 thousand tons.

It should be noted that there is a positive trend of growth in per capita consumption, both for meat and dairy products, outlined in 2018. It is important to preserve it and achieve a sustainable level of consumption not lower than in 2014.

Next, we will analyze and compare the level of self-sufficiency of the Rostov region with meat and dairy products for 2014 and 2018 (table 7). The level of self-sufficiency for these types of products is estimated using the self-sufficiency coefficient $\left(K_{c}\right)$, which characterizes the extent to which the region provides the population with milk and meat at the expense of local production, and is determined by the formula:

$$
K_{c}=\frac{q}{n * q_{p}}
$$

where $K_{c}$ is the self-sufficiency coefficient;

$q$ is the actual volume of food production in the region;

$n$ - the population of the region;

$q_{p}$ - rational consumption rates (from table 1 ).

The self-sufficiency coefficient $\left(K_{c}\right)$ can take a different value: to a low value of the indicator can be attributed $\left(K_{c} \leq 0,5\right)$, to an acceptable value $\left(0,5<K_{c} \leq 0,9\right)$; to the optimal level $\left(0,9<K_{c}\right)$.

Table 7. Level of self-sufficiency of the Rostov region with meat and dairy products for 2014 and 2018.

\begin{tabular}{|l|c|c|c|c|c|}
\hline Name & Year & $\begin{array}{c}\text { Population. thousand } \\
\text { people }(\boldsymbol{n})\end{array}$ & $\begin{array}{c}\text { Production. } \\
\text { thousand } \\
\text { tons }(\boldsymbol{q})\end{array}$ & $\begin{array}{c}\text { Necessary production } \\
\text { volumes. thousand tons } \\
\left(\boldsymbol{n} * \boldsymbol{q}_{\boldsymbol{p}}\right)\end{array}$ & $\boldsymbol{K}_{\boldsymbol{c}}$ \\
\hline \multirow{2}{*}{ Meat } & 2014 & 4245.53 & 181.2 & 297.19 & 0.61 \\
\cline { 2 - 6 } & 2018 & 4220.45 & 41.1 & 295.43 & 0.14 \\
\hline \multirow{2}{*}{ Milk } & 2014 & 4245.53 & 90.6 & 1401.0 & 0.07 \\
\cline { 2 - 6 } & 2018 & 4220.45 & 70.6 & 1392.6 & 0.05 \\
\hline
\end{tabular}

The analysis shows that in the Rostov region, the self-sufficiency rates for meat and dairy products in 2018 are at a fairly low level: the self-sufficiency rate for meat was $14 \%$, 
which is 47 percentage points less than in 2014. This circumstance can be explained by the fact that in the Rostov Region several large meat and poultry production companies were closed, which led to a sharp reduction in production volumes when the level of population consumption decreased slightly.

The level of self-sufficiency of the Rostov region with milk and dairy products in 2018 amounted 5\%, which is 2 percentage points lower than in 2014. The situation on the regional milk market has always been difficult, because it is simply unprofitable for producers to produce milk, since according to statistics, the average purchase price for raw milk in the Rostov region is 22.8 rubles per kilogram, when the prices for dairy products on store shelves are much higher than this purchase price and average 55.0 rubles per liter of milk. This can be explained by the fact that the Rostov market is oversaturated with dairy products from neighboring regions, where Kuban producers occupy a significant niche. Only a few companies located in the Rostov region can compete with their neighbors for a place in points of sale. Thus, only $13.6 \%$ of milk, $12.9 \%$ of fermented milk products, $28.6 \%$ of butter, and $16.7 \%$ of sour cream are produced by the Don manufacturer at Rostov counters.

\section{Results}

The analysis shows that the level of self-sufficiency of the Rostov region with meat and dairy products is at a significantly low level and makes up 14\% for meat and $5 \%$ for dairy products.

The low level of food self-sufficiency has developed due to the difficult situation on the market of milk and meat. Meat producers faced a number of difficulties, including such a problem as bird flu. As a result, two large producers suspended operations, which affected the decline in meat production in the region.

For dairy producers, the problem was the inability to compete successfully with products from other regions.

To increase the level of self-sufficiency of the Rostov region, it is possible to propose a protectionist policy towards local producers. This activity should be implemented on the basis of a number of principles:

- $\quad$ stimulating the development of the food and processing industry;

- $\quad$ support for food producers in order to provide them with the necessary profitability to enable expanded reproduction;

- protecting the economic interests of food consumers by regulating market prices;

- $\quad$ increasing the real income of the population by increasing employment, wages and social benefits;

- social support for low-income segments of the population in order to increase their level of food consumption;

- quality control of food sold.

The lack of self-sufficiency in dairy and meat products in the Rostov region is compensated by inter-regional commodity exchange.

An indicator of a high level of food security in the Russian Federation has always been a high level of self-sufficiency of regions. The output of the Rostov region to the indicators of self-sufficiency in milk and meat will satisfy the economic and social needs of the population, as well as to contribute the ensuring the country's food independence.

\section{Conclusions}


In modern conditions, one of the main tasks facing the domestic agro-industrial complex is the development of modern, highly efficient production [7].

For the successful implementation of the import substitution policy, state authorities need to concentrate their activities on the relevant areas. First of all, in our opinion, it is advisable to develop a new targeted regional program that will be aimed at supporting import substitution [8], creating all the necessary conditions to prevent the region's industry from depending on imports of goods and components. It is necessary to choose the most promising projects that will meet all the necessary requirements, in particular the prospects of production and innovation[9]. It is also important that these projects create jobs. It is necessary to set a course to displace foreign products of low and medium quality from the domestic market, and then concentrate efforts on creating alternative production that can replace the highest-quality goods imported from abroad [10].

Priority directions of improving the mechanisms of state regulation of the agricultural sector can be: strengthening of investment processes [11]; ensuring sustainable development of agricultural producers [12]; ensuring the social orientation of agricultural reforms, supporting vulnerable sections of the population; implementation of targeted programs for the development of the agricultural sector of the region, taking into account its specificity and the presence of multivariate management models [13]; ensuring the comprehensiveness and efficiency of using the resource potential of the agricultural sector; regulation of agricultural markets, promotion of wide introduction and dissemination of innovations [14]; creation of conditions for mutually beneficial cooperation of Russian regions, contributing to the achievement of a common goal-ensuring national food security and independence [15].

\section{References}

1. Z. Gornostaeva, O. Gribova, N. Tregulova, S. Vasenev, Lecture Notes in Networks and Systems Growth Poles of the Global Economy: Emergence, Changes and Future Perspectives, 159-166 (2020)

2. S. Vasenev, M. Bugaeva, M. Rossinskaya, V. Rokotyanskaya, M. Dikanov, International Journal of Economic Perspectives 11, 3 (2017)

3. S. Vasenev, N. Ovanesyan, M. Rossinskaya, S. Volgina, V. Rokotyanskaya, Journal of Advanced Research in Law and Economics 8(2), 644-657 (2017)

4. I. Slatvitskaya, D. Mironova, N. Zibrova, S. Romanova, N. Ryabocon, International Journal of Economics and Financial Issues 6(2), 253-259 (2016)

5. Z. Gornostaeva, O. Malinina, R. Kadukova, S. Vasenev, Contributions to Economics 9783319606958, 497-503 (2017)

6. N. Zaitseva, A. Larionova, Zh. Gornostaeva, O. Malinina, V. Povalayeva, S. Vasenev, I. Skrynnikova, A. Ersozlu, Eurasia Journal of Mathematics, Science and Technology Education 13(11), 7339-7351 (2017)

7. A. Nagoev, A. Smetanko, V. Rokotyanskaya, I. Lenkov, V. Gorbachev, International Journal of Supply Chain Management 9(1), 683-688 (2020)

8. I. Slatvitskaya, D. Mironova, S. Romanova, T. Popova, Academy of Strategic Management Journal 16(1), 225-238 (2017)

9. E. Cherkesova, D. Mironova, I. Slatvitskaya, T. Popova, European Research Studies Journal 21(1), 287-295 (2018)

10. A. Tatuev, S. Shanin, V. Rokotyanskaya, O. Moshchenko, J. Gladkova, Journal of Engineering and Applied Sciences 12(8), 2039-2044 (2017) 
11. A. Tatuev, A. Nagoev, N. Shash, E. Lyapuntsova, V. Rokotyanskaya, International Business Management 9(5), 928-934 (2015)

12. A. Tatuev, V. Rokotyanskaya, M. Rossinskaya, S. Tsvetcova, S. Evetskaya, International Journal of Economic Perspectives 11(2), 1-13 (2017)

13. A. Tatuev, G. Kutsuri, V. Rokotyanskaya, E. Lyapuntsova, S. Shanin, Journal of Applied Economic Sciences 12.3(49), 726-735 (2017)

14. E. Cherkesova, D. Mironova, I. Slatvitskaya, L. Simonyan, IOP Conference Series: Earth and Environmental Science 403, 012040 (2019) doi: 10.1088/17551315/403/1/012040

15. A. Tatuev, A. Zhankaziev, V. Rokotyanskaya, A. Anvarovna, N. Kiseleva, The Social Sciences (Pakistan) 10(9), 2292-2299 (2015) 